Шунейко А. А.

Mr. Alexandre A. Shuneyko

ОБУЧЕНИЕ РУССКОМУ ЯЗЫКУ КАК ИНОСТРАННОМУ В УСЛОВИЯХ

РОССИЙСКОГО ВУЗА: КОЛЛЕКТИВНАЯ МОНОГРАФИЯ. - ХАБАРОВСК: ИЗДАТЕЛЬСТВО ТОГУ, 2016.

\title{
TEACHING RUSSIAN AS A FOREIGN LANGUAGE AT RUSSIAN UNIVERSITIES: MULTI-AUTHORED MONOGRAPH. - KHABAROVSK: PACIFIC NATIONAL UNIVERSITY PRINTING HOUSE, 2016.
}

В современной России едва ли найдётся хоть один серьёзный вуз, в котором не было бы иностранных студентов и аспирантов. Соответственно, актуальность монографии определяется состоянием высшего образования. Механизмы обучения языку дифференцируются в соответствии с различными характеристиками и целевыми установками, свойственными конкретным группам учащихся. Использование одних и тех же методик применительно к ребёнку и аспиранту не всегда приводит к желанным результатам. Настоятельная потребность в детальной дифференциации методик - еще один показатель актуальности работы и её несомненной потенциальной востребованности.

Авторы монографии - дружный коллектив исследователей, которые не один год продуктивно трудятся в сфере преподавания русского языка как иностранного: Т.В. Васильева, Н.А. Выхованец, Е.В. Крапивник, Л.Ф. Крапивник, И.В. Семенова. Результативная практическая деятельность позволяет им производить систематические наблюдения и делать доказательные выводы, связанные с наиболее эффективными путями, обеспечивающими качественное усвоение русского языка представителями различных национальностей. Именно осмыслением практического опыта и ценна в первую очередь работа. Она рассматривает и обобщает различные теоретические вопросы и конкретные аспекты преподавания русского языка в вузовском формате.

Монография представляет собой оригинальный опыт описания наиболее эффективных и интересных современных методов, приемов и технологий обучения русскому языку как иностранному, анализа их лингводидактических, психологических и историкокультурных истоков и оснований, изложения примеров организации учебных занятий в рамках конкретной модели, реализующей концепции личностно-ориентированного обучения и коммуникативной методики преподавания иностранных языков.

Монография посвящена актуальной для преподавателей русского языка как иностранного теме - современным методам, приемам и технологиям обучения иностранцев в условиях современного российского вуза. Как известно, используемые в процессе обучения методы и приемы в значительной мере обуславливают выбор учебного материала, его объем и последовательность введения, определяют успешность и эффективность учебного процесса, а также влияют на процесс формирования не только компетенций учащихся, но и их мировоззрения и миропонимания.

В современной методике отмечается тенденция к активному поиску путей оптимизации процесса преподавания, сближению разных методов, выработке новых приемов, использованию инновационных технологий, которые обеспечивают эффективное обучение иностранному языку. Инновационные технологии и интенсивные методы обучения обеспечивают высокий уровень познавательной активности и учебной мотивации, позволяют усваивать материал системно, одновременно приобретая знания и умения, формируя компетенции разных видов - коммуникативной, языковой, речевой, лингвокультурной, профессиональной. Реализация компетентностного подхода при использовании инновационных технологий предусматривает широкое использование в учебном процессе активных и интерактивных 
форм проведения занятий: игровых форм при подаче и закреплении материала, ролевых игр, театрализации, внеаудиторной работы с использованием компьютерных технологий и пр.

Авторы монографии считают важным остановиться подробнее на вопросах использования методов, приемов, средств обучения, обеспечивающих успешное и эффективное обучение русскому языку как иностранному в условия современного российского вуза. Они не останавливаются отдельно на вопросах общей теории преподавания русского языка как иностранного. Каждая глава посвящена отдельному актуальному для современной методики вопросу - современным методам и приемам обучения русской фонетике, использованию игровых упражнений и аудиовизуальных технических средств на уроках русского языка как иностранного, формированию лингвокультурологической и профессиональной компетенций у иностранных студентов в условиях современного вуза. В монографии анализируются современные методы, приемы, технологии обучения, содержится информация об основах лингвистических, методических, психологических концепций, лежащих в основе описанных методов, приемов, технологий и средств, предлагается обзор учебных заданий и упражнений, реализующих данные методы и приемы.

По мнению авторов монографии, обеспечить за короткий срок достаточный уровень языковой подготовки иностранцев, научить их в течение ограниченного жесткими рамками учебного периода понимать речь носителей языка и решать повседневные бытовые и элементарные вопросы профессиональной направленности можно, разумно сочетая в процессе обучения традиционные и инновационные приемы и технологии.

Авторы монографии стремились не просто изложить постулаты ведущих методических концепций, существующих в современной методике преподавания русского языка как иностранного и оказывающих значительное влияние на отечественную лингводидактическую мысль, но и оказать практическую помощь желающим усовершенствовать свою профессионально-методическую подготовку, предложить свое понимание системы ориентиров для преподавателя при организации им образовательной деятельности и принятии педагогических решений.

Монография адресуется, прежде всего, преподавателям русского языка как иностранного, российским и зарубежным бакалаврам и магистрам-филологам, аспирантам и стажерам. Кроме того, материалы книги могут быть полезны всем интересующимся тенденциями развития современной методики обучения языкам.

Содержание монографии соответствует современному уровню лингводидактической науки и вносит в него ощутимый вклад. Читатель найдёт в книге массу полезного и в плане общих рекомендаций, и в аспекте конкретных интересных методических находок. 